\title{
IN MEMORIAM: PROFESSOR DR. GHEORGHE ROMANESCU
}

DOI: https://doi.org/10.18509/AGB.2019.06

UDC: 929Romanescu, $G$.

\section{Alin Mihu-Pintilie ${ }^{1}$, Cristian Constantin Stoleriu ${ }^{2}$}

\author{
${ }^{1}$ Institute for Interdisciplinary Research - Science Research Department, \\ Alexandru Ioan Cuza University of Iasi (UAIC), Romania \\ ${ }^{2}$ Department of Geography, Faculty of Geography and Geology, \\ Alexandru Ioan Cuza University of Iasi (UAIC), Romania
}

corresponding author: mihu.pintilie.alin@gmail.com

\author{
submitted: 15.12 .2018 \\ accepted: 25.12 .2018 \\ published: 18.01 .2019
}

\begin{abstract}
A great sense of loss and sadness marked the recent death of the great geographer Gheorghe Romanescu who passed away lightning on his way at his home in Iasi, the Romania on October 3, 2018 after a long battle with his weakened heart. Professor Dr. Romanescu was a highly respected member of the international Earth Science community, who devoted his life to understanding and describing the global issues of geography, especially in the field of hydrology, remaining highly active in his domain until the end of his life.
\end{abstract}

Gheorghe Romanescu was born on September $1^{\text {st }}$, 1959 in Malcoci (Tulcea County, SE Romania), a small village from Dobrogea, where he spent his childhood learning how to swim in Sf. Gheorghe branch or exploring the water labyrinth of the Danube Delta. Until the age when he had to leave to the port of Tulcea to attend high school studies, he was already known for wandering the banks of the Danube, a land of reeds and willows inhabited by an impressive ethnic and cultural mosaic. Due to the proximity to the water and nature, after high school, he attended the Faculty of Biology, Geography and Geology, specialization of Geography in French within Alexandru Ioan Cuza University of Iași graduating in 1985. Between the years 1985 - 1991 he returned to the port of Tulcea and taught Geography at the Industrial High School no. 4 (1985 - 1986) and at Gymnasium school no. 5 (1986 - 1991). The Revolution and the fall of the Communist regime in December 1989 found him on the Danube's cliff armed with an automatic pistol without a loader defending the city's heritage buildings from "imaginary terrorists". This memory was recalled every time among different circles of friends describing those moments as a "short military service".

The scientific interest of Gheorghe Romanescu in Earth sciences and water studies, apparently from an early age, led him to return to the academic environment in Iasi, just 6 years after graduating the geographic courses of the oldest university from Romania. Thus, between 1991 and 1996 he worked as a scientific researcher within the Geography team of the Romanian Academy. At the same time, in 1994 he became a doctor in Physical Geography at the Institute of Geography in Bucharest, with his paper work about the Danube Delta, a morphohydrographic study under the scientific coordination of Prof. Dr. Petre Gâștescu, one of the pioneers of the Romanian Limnology. This achievement was followed by a period of extensive research in fields of study related to deltaic and coastal hydro-morphology. Since 1995, when he was still a young researcher, and until 1998, following his interest in global water studies, he completed three postdoctoral studies: 1995 Sedimentology and Seacoast Geomorphology, Oceanography Institute, Southampton (UK); 1996 Limnology, Konstanz University, Konstanz (Germany); 1998 - Geomorphology and Hydrology, Sorbonne I University - Paris (France). In 1998, after the international experience on the shores of the Atlantic Ocean and the Alps, he transferred to the Department of Geography within the Faculty of History and Geography of the Stefan cel Mare University of Suceava, where he initially worked as Lecturer and later as Associate Professor until 2003. After acquiring a significant research experience and as an achievement of the scientific results of the last 10 years, in 2003 he transfers 
definitively to the Faculty of Geography and Geology, the Department of Geography of Alexandru Ioan Cuza University in Iasi, where he served as Professor until end of life.

Thanks to a diligent research work, as well as an unwavering passion for the exploration of the Earth, Professor Gheorghe Romanescu has made numerous contributions, both professional and didactic, to the development of modern Romanian Geography through significant studies in the field of Hydrology, Oceanography, Geomorphology (coastal dynamics, natural hazards, sedimentology of lacustrine complexes, etc.), Geo-archaeology and Wetlands. In the last 15 years $(2003-2018)$ he taught 35 university courses (e.g. Hydrology, Oceanography, Water Geography of Romania, Limnology, Hydrological Risks, Black Sea Geography, Hydrology of Delta and Estuaries, Seaside Geomorphology, etc.) and supported 28 practical works and university seminars (e.g. Hydrology and Oceanography, Limnology, Water Geography of Romania, Hydrological Risk Assessment, Black Sea Geography, Hydrology of Delta and Estuaries, Hydrographic and Coastal Network Development, Hydrotechnical Arrangement of River Basins, Tourist exploitation of coastal and delta regions, etc.).

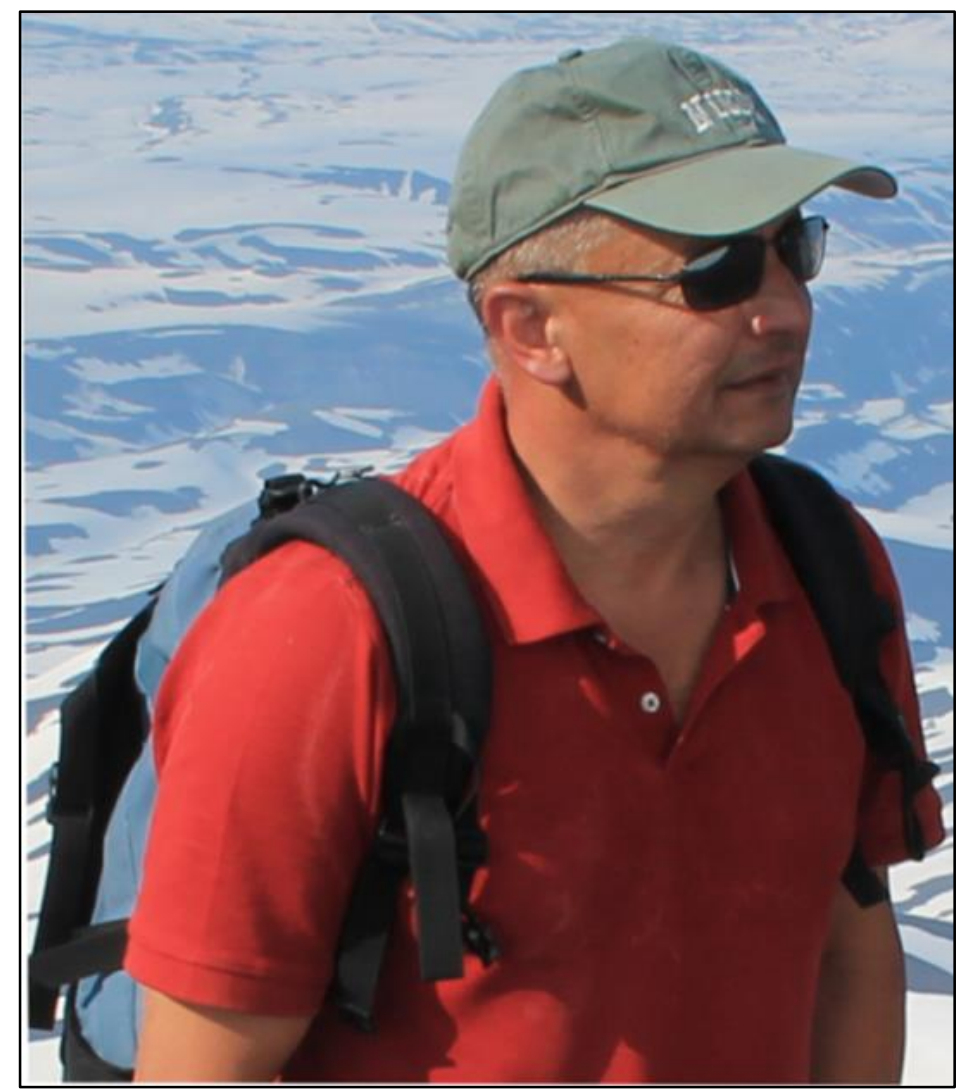

Figure 1. Professor Dr. Gheorghe Romanescu, Avachinski volcano, Kamchatka - 2014

Gheorghe Romanescu was an excellent speaker, a brilliant, enthusiastic and devoted researcher, a remarkable professor and an intellectually rigorous scientist characterized by the highest standards of personal and professional integrity. One of his key features was the ability to see the big picture, never losing sight of fine details. Since the beginning of his career, he has realized that water will become the most important socio-economic problem of humanity, thus stimulating his interest in raising and developing the study of water resources from an interdisciplinary and transdisciplinary perspective. From this point of view, he was one of the pioneers of the wetlands study in Romania and strengthened the cooperation in the field of hydrology in Europe. With his active and field- focused mind, he managed to connect the classical hydrology studies and GIS analysis, corroborated with information technology and mathematical statistics, always resorting to self-learning when he could not find anyone to show the link to a new discipline!

Perhaps the most representative professional characteristic of Professor Gheorghe Romanescu was scientific activity. $\mathrm{He}$ is the author of 51 courses and university books, including 12 books and book chapters published abroad. Here are worth mentioning the treaties The tourist potential of coasts and deltas. A look at the romanian coastal areas, Geomorphological Impacts of Extreme Weather. Case Studies from Central and Eastern Europe, or Limnology of the Red Lake, Romania. 
An Interdisciplinary Study. He also published 39 university courses and books in Romanian: Land Hydrology, Oceanography, Limnology, Inventory and Typology of Wetlands and Deep Waters in the Central Group of the Eastern Carpathians, so on. Nevertheless, he is the author of 152 articles published in international journals and 135 articles published in national journals. From this perspective, with 542 references in ISI quoted papers and several other thousands of citations in scientific journals indexed in other international databases and monographs, researcher Gheorghe Romanescu will remain one of the most cited Romanian geographers of all time, both at national level, but especially at international level.

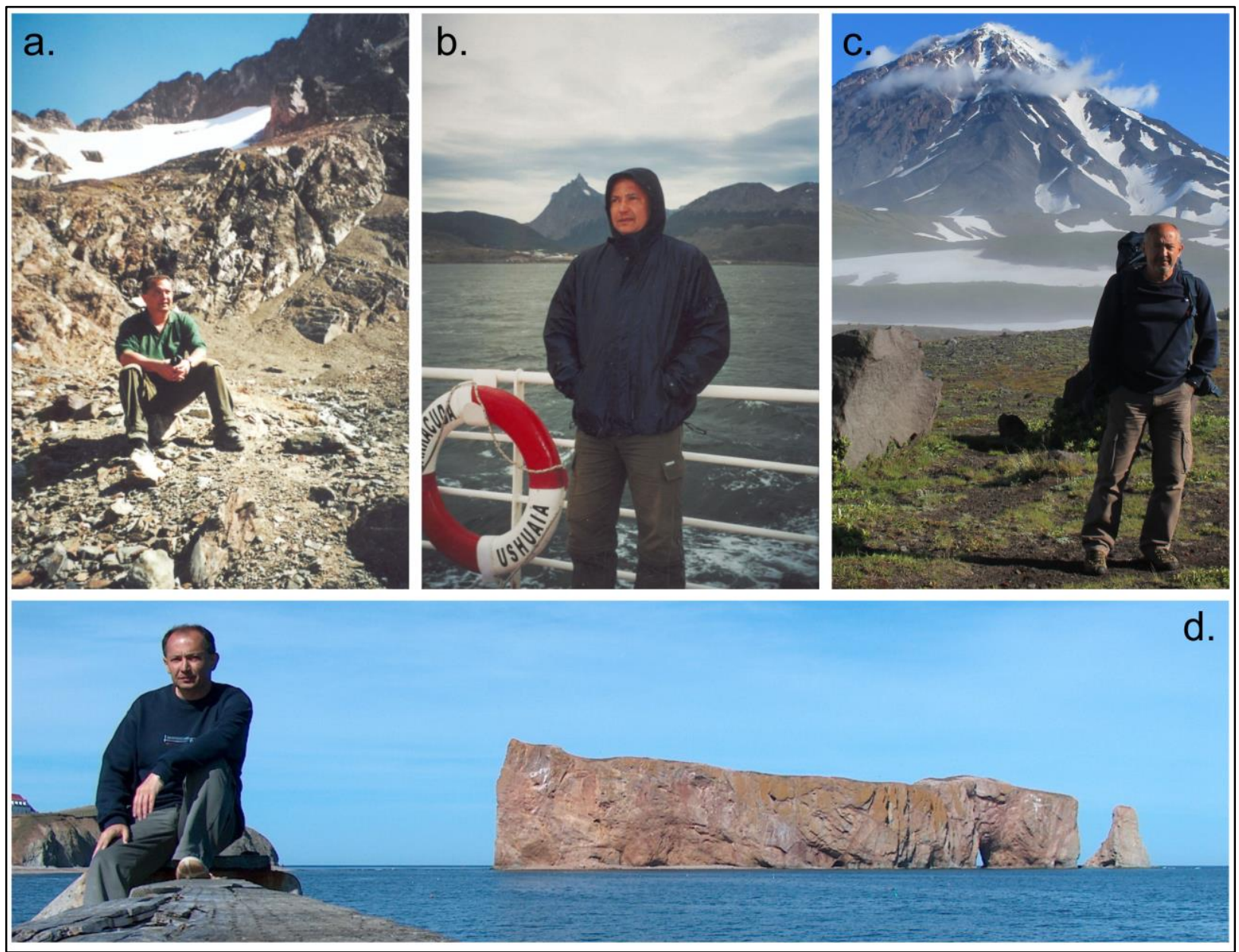

Figure 2. Photos around the world from the personal archieve of the Professor Dr. Gheorghe Romanescu: a. Scientific Expedition to the Andes, Altiplano - March 2008; b. Tierra del Fuego, Patagonia - Expedition "Ushuaia 2002"; c. Scientific Expedition to Kamchatka, Russia - June-July 2014; d. Expedition to Australia - July-August 2006.

In addition to being a very relevant reviewer and a passionate about the scientific literature, Gheorghe Romanescu has personally organized 15 sessions of scientific communications in prestigious Romanian institutions, moderated 55 national scientific sessions or under the aegis of international fora, and was associate editor / member of 43 scientific committees of prestigious scientific events, including the international scientific committee of Geobalcanica. He was also a member of 165 editorial committees of journals and specialized publishing houses as well as a scientific coordinator of 27 specialized books published at national and international publishing companies. As a result, throughout his life, he has received 35 national and international awards and prizes as recognition of his tremendous contributions to water research. Among these, we can mention the Umwelt und Wohnen, Gold Medal in 2012, 2014, 2015, and 2016 in the EUROINVENT salon, or the Book of the Year 2013 offered by the Romanian Geographical Society. From an administrative perspective, between 2007 and 2018 he was the scientific coordinator of 25 doctoral studies at the Doctoral School of Chemistry, Life Sciences and Earth at Alexandru Ioan Cuza University of Iași, Faculty of Geography and Geology, Department of Geography. At the same time, he was a mentor for 33 doctoral committees, a member in 25 committees for granting the title of doctor and a member in 1 
committee for granting the honoris causa degree. $\mathrm{He}$ was also part of 2 postdoctoral international committees for doctors in Cameroon and Côte d'Ivoire and a coordinator for 8 international scholars from Senegal, Côte d'Ivoire, Algeria, Tunisia and Romania. In addition, he was a board member of several councils of research institutions in Romania, from which is worth mentioning: Interdisciplinary Research Department - Fieald Science, Alexandru Ioan Cuza University of Iași; CERNESIM - Center for Studies in Environmental Science for the North - East Region, Alexandru Ioan Cuza University of Iasi, etc. Between 2006 and 2018, he was the Director of the Geoarchaeology Laboratory and between 2016 and 2018 he also held the position of Senior Researcher at CERNESIM Center for Studies in Environmental Science for the North - East Region at Alexandru Ioan Cuza University of Iași. Starting with 2017 he became Director of the Doctoral School of Geosciences, Alexandru Ioan Cuza University of Iași, Faculty of Geography and Geology.

As far as the passion for scientific expeditions is concerned, between 1994 and 2014, the adventurer Gheorghe Romanescu, has organized 14 scientific expeditions travelling on 5 continents: 1 . Scientific Expedition in the Atlantic Ocean (September October 1994) in collaboration with Southampton Institute of Oceanography, under the guidance of Professor M. Collins; 2. Scientific expedition to the southern sector of Baikal Lake - "Baikal 2001" (September - October, 2001); 3. Tierra del Fuego (Patagonia) Expedition - "Ushuaia 2002" (February 2002) (Figure 1.b); 4. Lapland Expedition (March 2005); 5. Scientific Expedition to Labrador (JuneJuly 2005); 6. India-Nepal Scientific Expedition (August-September 2005); 7. Expedition to Australia's Great Deserts (July-August 2006) (Figure 1.d); 8. Scientific Expedition to the Pampas of Argentina and Paraná Delta - South America (February 2008); 9. Atacama Desert Scientific Expedition (March 2008); 10. Scientific Expedition to the Andes (Altiplano) (March 2008) (Figure 1.a); 11. Scientific Expedition to Amazonia (March 2008); 12. Scientific Expedition to Alaska (MayJune 2008); 13. Expedition to the Sahara Desert (August 2008); 14. Scientific Expedition to Kamchatka, Russia (June-July 2014) (Figure 1.c). In addition to its stunning stories about the pink dolphins in the Amazon, the snowy peaks of the Andes or the depth of Baikal Lake, which he often shared with his students during courses and seminars, the adventurer Gheorghe Romanescu left a legacy and an impressive collection of photographs (> 100,000 pictures) from all over the world.

As a person, Gheorghe Romanescu was much more than the sum of all the scientific and academic achievements gained during his life and everyone who had the privilege and the joy of working with him can testify this. It is difficult to describe the magnitude of its influence on the geographic community around the world, but the terms "spider flow" and "loesscape" have been frequently cited lately. He was a great mentor not only for the 25 $\mathrm{PhD}$ students he trained, but also for a wide range of students, master students, academic assistants, researchers and in the past few years to anyone around the world who sought his help and advice. Those who met him, either in the university's amphitheatres where he lectured or through his expeditions, were immediately impressed not only by his contagious enthusiasm for any problem to be solved, but also by his vision, combined with force and determination to fulfil his duty as a researcher. Since he passed away, many colleagues have expressed their gratitude, admiration and respect for him, acknowledging the impact he had on their lives, even if some of them have met him only occasionally. They all mentioned it was a privilege to know and work with such a geographic personality. It is not just about his impressive collection of scientific works, easily accessible and shared with others as an inheritance for future generations, but also about the memory of Gheorghe Romanescu as a free spirit. If it is difficult for us, as a scientific community, to imagine that he is no longer around to discuss a wide range of geographic issues, but even harder for his family to whom, through this manuscript, we express our sincerest condolences.

The death of Professor Gheorghe Romanescu is the sad loss of an astonishing individual, whose contribution to Earth sciences is immeasurable. His material and spiritual legacy will remain in the collective memory of the international academic and scientific environment as a prestigious didactician, explorer and exceptional geographer. The tribute to water memory through its specialized work in the field of hydrology, limnology, oceanography and delta and coastal geomorphology, will for a long time inspire new generations of geographers. On behalf of the alma mater iassiensis and the Geobalcanica community, the authors dedicate this short article to the family and friends of the great geographer of the waters! 